\title{
FURTHER STUDIES ON MARE SERUM GONADOTROPHINS SECRETED IN RESPONSE TO IMMUNIZATION WITH HCG OR CRUDE OVINE FSH
}

\author{
R. B. SNOOK,* H. H. COLE AND I. I. GESGHWIND \\ Department of Animal Husbandry, University of California, Davis, California \\ (Received 6th February 1967, revised 24th April 1967)
}

Summary. The gonadotrophic activity of sera from two mares treated either with human chorionic gonadotrophin or with crude ovine pituitary FSH as antigens has been studied in intact and hypophysectomized immature female and male rats. The studies were projected over a 4-year period during which time the mares were subjected to three and four sequences of immunization, respectively.

One-third millilitre of serum from the mare treated with ovine FSH increases ovarian and uterine weights in intact immature female rats, while $5 \mathrm{ml}$ of serum tends to depress these weights because of the antiFSH present in the serum. Thirty millilitres of serum approximately doubles the seminal vesicle and prostate weights in intact males, whereas the testis weights are either unaffected or depressed. Based on the ventral prostate responses in Sprague-Dawley hypophysectomized males, the serum is estimated to contain about 25- $\mu$ g equivalents of NIH-LH-s8/ml. Both the serum of this mare and that of an untreated non-pregnant mare depressed the ovarian ascorbic acid level significantly, but the slopes of the responses to graded doses were flat and thus LH values could not be estimated by this procedure.

The biological activity of the serum from the mare treated with HGG as an antigen has been previously described. In earlier studies, Long-Evans hypophysectomized males, operated upon at 23 to 26 days, were used with treatment starting 15 days later. The testes were enlarged but the ventral prostate weights were unaffected by $16 \mathrm{ml}$ of serum. In more recent findings, it has been found that if the animals are operated upon at 21 days and injections begun 4 days later significant ventral prostate weight responses can be obtained with $8 \mathrm{ml}$ of serum. Attempts have been made to separate the gonadotrophic and anti-gonadotrophic activities in this serum by chemical fractionation. From the localization of activities in the $\gamma$-globulin fractions of the ammonium sulphate-ethanol procedure, and the $\alpha$ - and $\beta$-globulin fractions of the DEAE-cellulose procedure we conclude that the gonadotrophic and anti-gonadotrophic activities are not following any of the classical serum proteins for which

* Present address: Department of Animal Husbandry, Cornell University, Ithaca, New York. 
these procedures were devised. It is suggested that most of the contaminating serum proteins could be eliminated by the sequential use of both procedures.

\section{INTRODUCTION}

Earlier studies (Snook \& Cole, 1964) showed that the injection of human chorionic gonadotrophin (HCG) as an antigen into mares resulted in high anti-HCG titres with subsequent increased secretion of FSH by the pituitary of the mare. The serum of the mare produced the following effects: (1) in immature female rats, the ovarian weights were increased about $50 \%$ and the uterine weights were doubled over those of uninjected controls; the number of larger follicles was increased but none reached mature size; (2) no detectable response was observed in hypophysectomized female rats with doses as high as $30 \mathrm{ml}$ of serum; (3) the weights of the testes of hypophysectomized male rats were 30 to $50 \%$ greater than those of controls, but the sex accessories were unaffected; and (4) the testes and sex accessories of intact immature male rats were unaffected by a $1 \mathrm{ml}$ dose of serum; 5 or $30 \mathrm{ml}$ of serum reduced the testes and sex accessory weights below those of untreated controls.

In the present paper we will report on the gonadotrophic activities in the serum of a mare treated with ovine pituitary FSH as an antigen. We will also report further studies on gonadotrophins in the serum of the mare treated with HGG as an antigen and describe preliminary attempts to separate chemically the gonadotrophic and anti-gonadotrophic activities in the serum.

\section{MATERIALS AND METHODS}

Gonadotrophins used as antigens

A commercial preparation of HCG with about 3000 i.u./mg was used. The FSH (supplied by C. H. Li) was a relatively crude ovine pituitary preparation; a total dose of $9 \mathrm{mg}$ distributed in three daily injections produced ovaries weighing 45 to $60 \mathrm{mg}$ in intact immature female Long-Evans (L-E) rats 23 days old at first injection. One-half of this dosage $(4.5 \mathrm{mg})$ distributed in four daily injections produced a $265 \%$ increase over uninjected controls in the ventral prostate weights of Sprague-Dawley (S-D) male rats hypophysectomized at 21 days of age; injections were begun at 24 days, with autopsy at 28 days of age.

Rats used for assay

For studies on total gonadotrophic activity and for anti-gonadotrophic activity intact immature L-E female rats were used. Initially the rats were given the first injection on the 25th day with autopsy $96 \mathrm{hr}$ later, but the uteri of some control animals were enlarged at this age. Therefore, in later studies the injections were begun at 23 days. Details of the assay for anti-HCG activity have been published (Snook \& Cole, 1965). To test for anti-FsH activity the serum was given in a single injection and the FSH administered over a 3-day period. By serially halving the dose, the smallest amount of serum which would completely inhibit the response to an amount of FSH which alone produced 45 to $60 \mathrm{mg}$ ovaries was determined. 
As a measure of both LH and FSH activities, a single injection of serum was given to 23- to 25-day-old females with necropsy $96 \mathrm{hr}$ later. The ovaries and uteri were weighed and macroscopic observations made of follicular development and luteinization. Some of the ovaries were sectioned for histological examination.

Intact immature males were used weekly or bi-weekly for rough approximations of the circulating LH levels, and also to provide some information on the anti-gonadotrophic activity of the serum, as determined by the depression of testes weights. A total dose of $30 \mathrm{ml}$ of serum was distributed in six injections over a 3-day period. Our decision to use intact males was predicated on an assumption, later proved to be incorrect, that it would not be possible to give sufficient serum to elicit a response in hypophysectomized animals.

Levels of LII were quantitatively determined in hypophysectomized males using the ventral prostate (VPW) method of Greep, Van Dyke \& Chow (1941) or a modification of it. Attempts were made to determine the LH content in intact females using the Parlow (1961) ovarian ascorbic acid depletion (OAAD) assay.

\section{TABLE 1 \\ INJECTION OF MARES 665b (CURLY) AND 665a (FORBES) WITH GONADOTROPHINS AS ANTIGENS*}

\begin{tabular}{|c|c|c|c|}
\hline Series & Period of injection & Series & Period of injection \\
\hline $\begin{array}{l}\text { Mare } 665 b \dagger \\
1 \\
2 \\
3\end{array}$ & $\begin{array}{l}\text { 5th July to 29th September } 1961 \\
\text { 3rd January to } 26 \text { th February } 1962 \\
\text { 30th November } 1962 \text { to } \\
\text { 9th January } 1963\end{array}$ & $\begin{array}{l}4 \\
5 \\
6\end{array}$ & $\begin{array}{l}\text { 2nd January to } 31 \text { st January } 1964 \\
\text { 17th June to } 27 \text { th July } 1964 \\
11 \text { th February to 18th March } 1966\end{array}$ \\
\hline $\begin{array}{l}\text { Mare } 665 \mathrm{a} \ddagger \\
1 \\
2 \\
2\end{array}$ & $\begin{array}{l}\text { 11th July to } 11 \text { th September } 1960 \\
\text { 14th December } 1960 \text { to } \\
\text { 10th February } 1961 \\
\text { 10th April to 18th April } 1961\end{array}$ & $\begin{array}{l}5 \\
6 \\
7\end{array}$ & $\begin{array}{l}\text { 3rd January to } 12 \text { th February } 1963 \\
\text { 28th November } 1962 \text { to } \\
7 \text { th January } 1963 \\
\text { 2nd January to 31st January } 1964\end{array}$ \\
\hline
\end{tabular}

* As a routine procedure the hormone was administered twice weekly in saline and once weckly with Freund's adjuvant.

$\dagger$ During the first half of the first two series this mare received $5750 \mathrm{i} . \mathrm{u}$. or more of HCG thrice weekly and in the second half $200 \mathrm{mg}$ of FSH. In subsequent series she received only FSH, the dosage being $200 \mathrm{mg} 3$ times weekly.

$\ddagger$ This mare was treated 3 times weekly with daily dosages of 5746 i.u. to 11,500 i.u. of HCG.

\section{Mares used}

Two draft mares, mare 665b (previously designated as Curly) and mare 665 a (previously designated as Forbes), about 12 years of age and weighing approximately $1500 \mathrm{lb}$, were injected with antigen. Details of the treatment are given in Table 1.

Chemical fractionation procedures. Two different antisera collected from mare 665a, which showed good gonadotrophic activity, were subjected to chemical fractionation in an attempt to separate the gonadotrophic activity from the anti-gonadotrophic activity. A 485-ml aliquot of serum collected on 7th March 
1962 was fractionated with ammonium sulphate and ethanol according to a modification of the procedure described by Deutsch \& Nichol (1948). The other sample, consisting of a pooled sample (collected on 6th and 15th February 1963) was fractionated on a diethylaminoethyl (DEAE) cellulose column with an exchange capacity of $0.97 \mathrm{~m}-\mathrm{eq} / \mathrm{g}$. Sixty millilitres of antisera were applied to the top of a $60 \times 3 \mathrm{~cm}$ column which contained $30 \mathrm{~g}$ of absorbent. The eluting systems employed were slight modifications of one described by Sober, Gutter, Wyckoff \& Peterson (1956) and consisted of a series of discontinuous linear or convex gradients. The details of one such experiment are given in Text-fig. 1 .

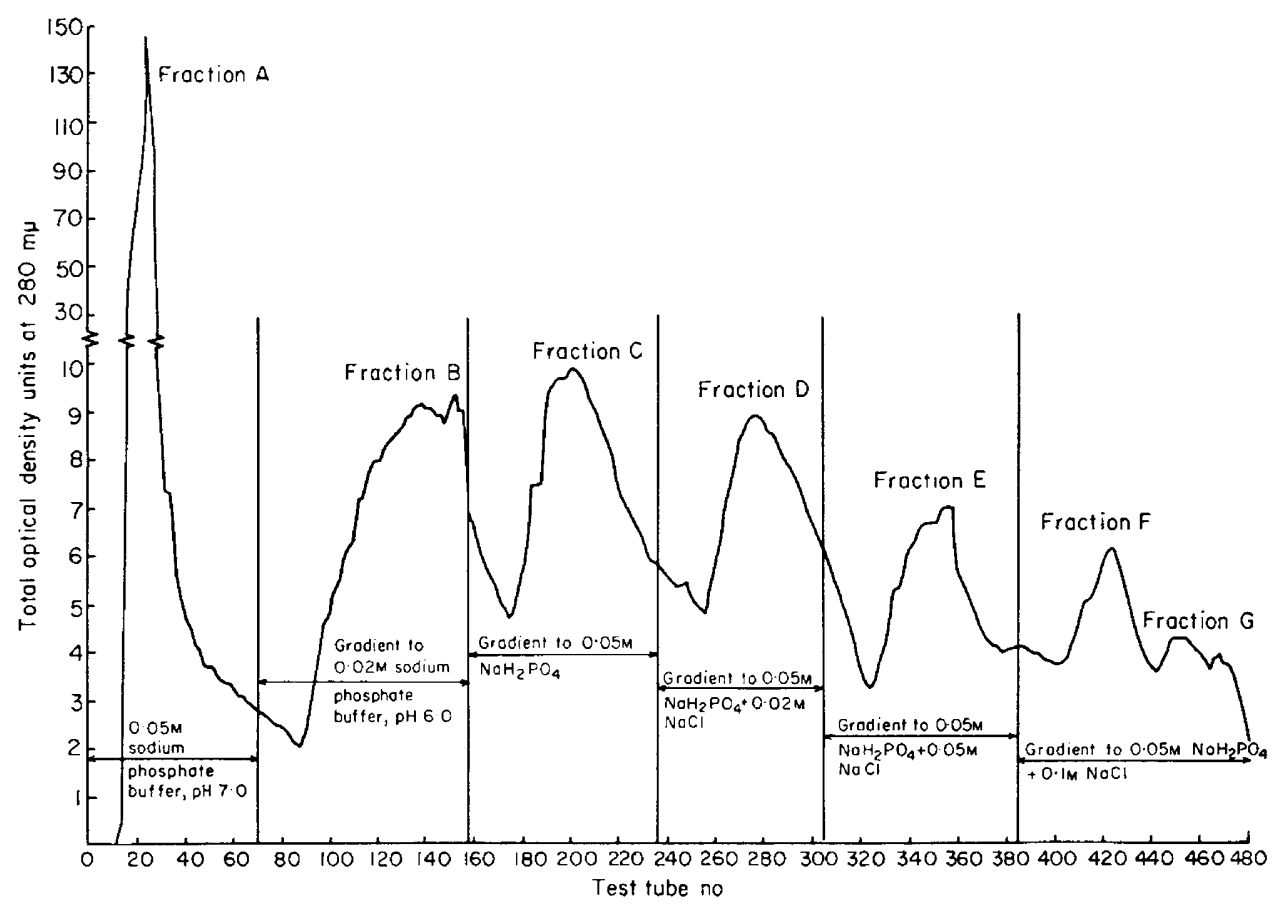

TEXT-FIG. 1. Fractionation of $60 \mathrm{ml}$ of pooled serum from mare 665a (6th and 15th February 1963), dialysed against starting buffer, and eluted from DEAE-cellulose. The break-through peak was eluted with starting buffer $(0.005$ m sodium phosphate buffer, $\mathrm{pH} 7 \cdot 0$ ). Succeeding fractions were eluted by increasing the ionic strength and decreasing the $\mathrm{pH}$ of the eluting agent. Vertical lines represent the point at which a new gradient was started. Effluent collected in 5-ml fractions. Run No. 2.

A new gradient was started when the peak eluted by the preceding gradient reached baseline level and showed no indication of rising again. The pattern shown in Text-fig. 1 represents one of the later runs in which, to save time, the new buffers were introduced before the peaks reached baseline, earlier experiments having shown when the gradient changes could be imposed.

Fractions of $5 \mathrm{ml}$ were collected and read at $280 \mathrm{~m} \mu$ on the Beckman DU. Total optical density per tube was plotted against tube number. The tubes forming a peak were pooled, then dialysed against distilled water at $5^{\circ} \mathrm{C}$ and lyophilized. The fractions were weighed and stored until they were assayed. Each fraction was subjected to paper electrophoresis employing a $\mathrm{pH} 8.6$ barbital buffer to help identify the serum proteins it contained. 


\section{RESULTS}

Studies on the serum of Mare $665 b$ receiving ovine pituitary FSH as an antigen

The effect of the serum collected following the first two series of injection of antigens has been reported (Snook \& Cole, 1964). Some data collected following the third series were also reported but more complete data are now available and are cited along with information obtained in the three subsequent series of injections. These additional studies on sera collected after the third series are of interest because they point out that the ovaries of immature intact female rats may be stimulated or inhibited by varying the dosage. Large doses appear to inhibit endogenous FSH in immature females.

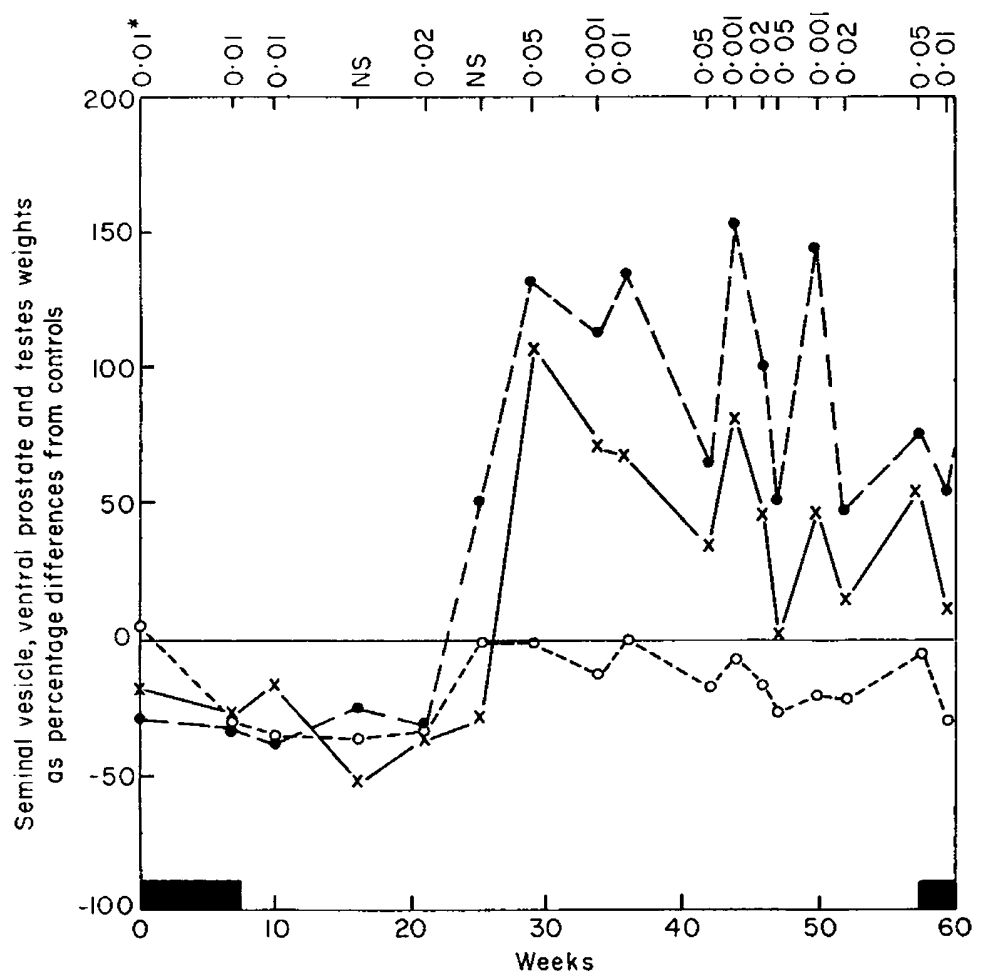

TEXT-FIG. 2. Responses of intact immature male rats to $30 \mathrm{ml}$ of serum of mare $665 \mathrm{~b}$ collected during and subsequent to the third series of injection of FSH as an antigen. The rats were injected twice daily for 3 days with necropsy $96 \mathrm{hr}$ after the initial injection. The points are the averages of a minimum of three animals. The figures at the top of the graph indicate the significance of the difference of the seminal vesicle weights from those of six uninjected controls. The bars along the abscissa indicate the period of injection. $\times$, ventral prostate; $O$, seminal vesicles; $O$, testes.

Effect of the serum on the testes and sex accessories of intact male rats. The effect of the serum on the testes, prostate and seminal vesicles of intact immature males for 60 weeks after beginning the third series of injections is shown in Text-fig. 2 . Prostate and seminal vesicle weights parallel each other closely, but the percentage increases in the weight of the seminal vesicles regularly exceed those of the prostate. One might interpret this as indicating that less androgen (and consequently less LH) is needed for prostate development. Therefore, the prostate 
of intact immature males develops fairly rapidly and thus is less affected by exogenous LH. On the other hand, the prostate of the hypophysectomized male, with little or no endogenous LH, is more sensitive than are the seminal vesicles to exogenous hormone. During the interval when the serum produces increases in weight of the sex accessories, the testes weights remain at control levels or, more frequently, below (Text-fig. 2). This depression in testes weight, we suggest, depends upon the presence of anti-FSH which inhibits the endogenous FSH of the rat. Though the serum of the mare has some FsH activity, as can be demonstrated in the intact female rat, it is apparently insufficient to compensate for the loss of the endogenous FsH of the immature male rat.

Although studies on the responses of the intact immature male rat to the serum of mare $665 \mathrm{~b}$ were continued for a 2-year period, only the first year's results are shown in Text-fig. 2. Following the third series of injections, as shown in Text-fig. 2, the serum depressed the prostate and seminal vesicle weights for about 20 weeks. This depression may be due to residual anti-HCG from the second series of injections (see Table 1). A similar depression was not observed following the fourth and fifth series of injections. Over the 2-year period no significant changes in either anti-FSH or anti-HGG were observed. It took 0.5 to $2 \mathrm{ml}$ of serum to inhibit completely an amount of crude FSH producing 50 $\mathrm{mg}$ ovaries and about $1 \mathrm{ml}$ to inhibit 20 i.u. of HcG.

Qualitative effects of the serum on the testes of the hypophysectomized male rat. To show the qualitative effect of the serum, rats were hypophysectomized at 23 to 26 days of age and injections were begun 15 days after the operation.

In eight separate tests, involving 128 hypophysectomized rats and using four different sera with dosages ranging from 7.5 to $30 \mathrm{ml}$ of serum/rat, the testes were significantly increased in weight in seven instances. In six out of eight instances measurements showed that the diameters of seminiferous tubules were significantly greater than those in hypophysectomized control animals. Histological examination of the testes showed that the degree of repair of the interstitial tissue varied from slight to nearly complete. There is reasonable certainty that the effect upon the interstitial tissue depended solely upon LH. On the other hand, it is probable that both FSH and LH in the serum contributed to the enlargement of the seminiferous tubules.

Quantitative measurement of $L H$ activity in the serum. Five VPW assays using three different sera were made, using hypophysectomized L-E rats. Ventral prostate weights of rats receiving the ovine standard (NIH-LH-s8) were determined concurrently. The range in relative mean potency was 8.5 to $20.9 \mu$ g-equivalents of $\mathrm{LH}-\mathrm{s} 8 / \mathrm{ml}$ of serum. The high lambda values $(0.365$ to 0.598$)$ obtained were due to the small slope and the large individual variations in ventral prostate weight responses.

Two sera used had been stored for a considerable period before testing. However, we have not noted any deterioration during storage. For example, the composite serum (25th March and 19th April 1964) filtered and merthiolated to prevent bacterial contamination, was tested in 23-day hypophysectomized S-D male rats about 20 months after collection. The average weight of the ventral prostates of six rats receiving $2 \mathrm{ml}$ of serum was $23.6 \mathrm{mg}$ and of six rats receiving $8 \mathrm{ml}$ of serum was $39.7 \mathrm{mg}$ (the ventral prostates of six controls 
weighed $7.9 \mathrm{mg}$ ). These responses are comparable to those obtained with the freshly drawn serum.

The responses of 23-day hypophysectomized S-D males to sera of mare 665b collected during and subsequent to the sixth series of injections are shown in Tables 2 and 3 . Tests of the ovine standard were not run concurrently but a single test was run later. Only those tests of sera in which the average weights of the prostates of uninjected controls were comparable to those of the uninjected controls for the standard were used in calculating relative mean potencies (Table 2). The ventral prostate responses in 23-day S-D males are much greater than in 25-day L-E males; also the slopes are much steeper. Values for relative mean potencies are higher. The responses to $8 \mathrm{ml}$ of serum are greater in some instances than those obtained by Segaloff, Steelman \& Flores (1956) by administering $120 \mu \mathrm{g}$ of Armour ovine LH reference standard (sL-227-80) plus 5 i.u. of

\section{TABLE 2}

RELATIVE POTENCY ESTIMATES OF LH ACTIVITY IN THE SERUM OF MARE 665b BY THE VENTRAL PROSTATE WEIGHT ASSAY IN 23- OR 24-DAY-OLD S-D MALES HYPOPHYSECTOMIZED AT 21 DAYS

\begin{tabular}{c|c|c|c|c|c|c}
\hline $\begin{array}{c}\text { Date serum } \\
\text { collected }\end{array}$ & $\begin{array}{c}\text { Mean ventral } \\
\text { prostate weights } \\
\text { for each level of } \\
\text { LH standard* }(\mathrm{mg})\end{array}$ & $\begin{array}{c}\text { Mean ventral } \\
\text { prostate weights } \\
\text { for each level of } \\
\text { serum }(\mathrm{mg})\end{array}$ & $\begin{array}{c}\text { Combined } \\
\text { slope }\end{array}$ & $s$ & $\lambda$ & $\begin{array}{c}\text { Relative } \\
\text { potency } \dagger\end{array}$ \\
\hline 11 th February 1966 & $\begin{array}{c}16 \cdot 3(30), 22 \cdot 4(60), \\
24 \cdot 6(120)\end{array}$ & $18 \cdot 8(2), 30 \cdot 0(8)$ & $16 \cdot 4$ & $5 \cdot 3$ & $0 \cdot 32$ & $23 \cdot 81$ \\
7th June 1966 & $20 \cdot 2(2), 38 \cdot 0(8)$ & $21 \cdot 8$ & $6 \cdot 2$ & $0 \cdot 28$ & $33 \cdot 78$ \\
\hline
\end{tabular}

Figures in parentheses following ventral prostate weights refer to dosage of NIH-LH-s8 standard employed in $\mu \mathrm{g}$ or dosage of serum employed in $\mathrm{ml}$.

* LH controls were run on a different date than either of the serum samples; however, the noninjected control values were similar.

$\dagger$ In $\mu$ g-equivalents of NIH-LH-s8/ml of serum.

prolactin to S-D males in which injections were begun 2 days after hypophysectomy. Lostroh, Squire \& Li (1958) reported that "Animals of the SpragueDawley strain showed an enhancement in their prostatic response to ICSH when either growth hormone or lactogenic hormone was administered along with the rCSH." They did not note this enhancement with lactogenic hormone in the L-E strain. It is not our purpose in the present study, however, to attempt to identify factors possibly augmenting the $\mathrm{LH}$ response. The serum of this mare produced excellent ventral prostate responses for a long period following cessation of treatment with antigen (Table 3). Note that in most instances $2 \mathrm{ml}$ of serum sufficed to produce significant increases in weights of both ventral prostates and testes.

We have attempted to assay $\mathrm{LH}$ in the serum of mare $665 \mathrm{~b}$ by the OAAD method. Though the serum in most instances depressed the ovarian ascorbic acid level significantly below the saline control level, there was, for all practical purposes, no slope in the dose-response curve. In two of three assays where a three-fold dose interval was employed, all responses were significantly different from the response to saline, but the response to the higher dose was the same as

C 
that to the lower. The serum from an untreated mare likewise reduced ovarian ascorbic acid but no evidence of $\mathrm{LH}_{\mathrm{H}}$ was obtained when the same serum was tested by the VPW method, whereas the serum of mare $665 \mathrm{~b}$ produced a threefold increase in VPW when tested concurrently (Table 4). Obviously, either the ventral prostate weight increases obtained with the serum of mare $665 \mathrm{~b}$ are the result of something other than LH or the OAAD method of assay is not an effective means of determining the $\mathbf{L H}$ levels in the serum of the mare.

\section{TABLE 3}

EFFECT OF SERUM OF MARE 665b (GURLY) GOLLEGTED DURING AND FOLLOWING THE SIXTH SERIES OF INJECTIONS OF ANTIGEN, ON VENTRAL PROSTATE AND TESTES WEIGHTS IN HYPOPHYSECTOMIZED SPRAGUEDAWLEY RATS

\begin{tabular}{|c|c|c|c|c|c|}
\hline $\begin{array}{l}\text { Date serum } \\
\text { collected }\end{array}$ & $\begin{array}{c}\text { Weeks } \\
\text { after } \\
\text { first } \\
\text { injection }\end{array}$ & $\begin{array}{c}\text { Dose } \\
\text { of } \\
\text { serum }\end{array}$ & $\begin{array}{c}\text { No. of } \\
\text { rats }\end{array}$ & $\begin{array}{c}\text { Ventral } \\
\text { prostate } \\
\text { weight } \\
(\mathrm{mg})\end{array}$ & $\begin{array}{c}\text { Testes } \\
\text { weight } \\
(m g)\end{array}$ \\
\hline 11th February 1966 & 0 & $\begin{array}{l}\text { None } \\
2 \mathrm{ml} \\
8 \mathrm{ml}\end{array}$ & $\begin{array}{l}5 \\
6 \\
6\end{array}$ & $\begin{array}{c}5 \cdot 3 \\
18 \cdot 8^{*} \\
30 \cdot 0 \dagger\end{array}$ & $\begin{array}{l}121 \cdot 6 \\
162 \cdot 0^{*} \\
206 \cdot 7 \dagger\end{array}$ \\
\hline 3rd March 1966 & 3 & $\begin{array}{l}\text { None } \\
1 \mathrm{ml} \\
4 \mathrm{ml}\end{array}$ & $\begin{array}{l}6 \\
5 \\
6\end{array}$ & $\begin{array}{c}7 \cdot 1 \\
10 \cdot 2 \\
12 \cdot 5^{*}\end{array}$ & $\begin{array}{l}145 \cdot 1 \\
165 \cdot 8^{*} \\
192 \cdot 6 \dagger\end{array}$ \\
\hline 25th March 1966 & 6 & $\begin{array}{l}\text { None } \\
2 \mathrm{ml} \\
8 \mathrm{ml}\end{array}$ & $\begin{array}{l}6 \\
6 \\
7\end{array}$ & $\begin{array}{c}\overline{11 \cdot 2} \\
30 \cdot 1 \dagger\end{array}$ & $\begin{array}{l}139 \cdot 7 \\
169 \cdot 7 * \\
228 \cdot 1 \dagger\end{array}$ \\
\hline 19th April 1966 & 9 & $\begin{array}{l}\text { None } \\
2 \mathrm{ml} \\
8 \mathrm{ml}\end{array}$ & $\begin{array}{l}6 \\
6 \\
6\end{array}$ & $\begin{array}{l}11 \cdot 3 \\
22 \cdot 5^{*} \\
40 \cdot 0 \dagger\end{array}$ & $\begin{array}{l}162 \cdot 9 \\
211 \cdot 5^{*} \\
240 \cdot 8^{*}\end{array}$ \\
\hline 11th May 1966 & 12 & $\begin{array}{l}\text { None } \\
2 \mathrm{ml} \\
8 \mathrm{ml}\end{array}$ & $\begin{array}{l}6 \\
6 \\
6\end{array}$ & $\begin{array}{l}11 \cdot 3 \\
35 \cdot 4^{*} \\
46 \cdot 6^{*}\end{array}$ & $\begin{array}{l}162 \cdot 9 \\
221 \cdot 8^{*} \\
296 \cdot 1 \dagger\end{array}$ \\
\hline 7th June 1966 & 15 & $\begin{array}{l}\text { None } \\
2 \mathrm{ml} \\
8 \mathrm{ml}\end{array}$ & $\begin{array}{l}6 \\
6 \\
5\end{array}$ & $\begin{array}{c}8.7 \\
20 \cdot 2^{*} \\
38.0 \dagger\end{array}$ & $\begin{array}{l}157 \cdot 8 \\
217 \cdot 3 * \\
347 \cdot 1 \dagger\end{array}$ \\
\hline 28th July 1966 & 23 & $\begin{array}{l}\text { None } \\
2 \mathrm{ml} \\
8 \mathrm{ml}\end{array}$ & $\begin{array}{l}5 \\
4 \\
6\end{array}$ & $\begin{array}{l}13 \cdot 6 \\
26 \cdot 5^{*} \\
42 \cdot 1 \dagger\end{array}$ & $\begin{array}{l}155 \cdot 4 \\
222 \cdot 9^{*} \\
258 \cdot 1^{*}\end{array}$ \\
\hline
\end{tabular}

Rats were hypophysectomized at 21 days of age and injections were begun 2 days later. Serum was injected once daily for 4 days.

* Significantly $(P \leqslant 0.05)$ heavier than those from uninjected controls.

† Significantly $(P \leqslant 0.05)$ heavier than those of animals receiving the lower dose.

Effect of the serum in intact and hypophysectomized immature female rats. Text-fig. 3 shows the effect of 0.3 or $0.6 \mathrm{ml}$ and of $5 \mathrm{ml}$ of serum drawn subsequent to the third and fifth series of injections upon the ovaries and uteri of immature intact female rats. Note that toward the end of the third and fifth immunization series the ovarian and uterine weights are less than those of uninjected controls. This could be interpreted as being due to the inhibition of endogenous FSH of the rat. Five millilitre doses of serum depress ovarian and uterine weights below control levels in the period in which $0.3 \mathrm{ml}$ or $0.6 \mathrm{ml}$ stimulates these 
organs (Text-fig. 3). Inasmuch as it is known, on the basis of the prostate response in the male, that equine serum LH can be, at most, only partially inactivated by equine antibodies against ovine LH (recall that a crude ovine FSH with considerable LH activity was used as the antigen) one could speculate further that equine serum FSH is not completely inhibited by antibodies against ovine FSH.

Although there is conflicting opinion concerning the necessity for $\mathrm{LH}$ in uterine development (Greep, 1961; Gemzell \& Roos, 1966; Segaloff, 1966), there is general agreement that FSH is required. Lostroh \& Johnson (1966) report that neither ovine FSH nor LH alone has an effect upon the uterus of the hypophysectomized female rat. The marked weight responses of the uteri of rats injected with $0.3 \mathrm{ml}$ of serum (Text-fig. 3) mean, therefore, that FSH may come either from the injected serum or from the pituitary of the recipient rat. To our knowledge, however, there is no convincing evidence that the pituitary of the immature female rat secretes sufficient FSH to synergize with exogenous pituitary LH. Therefore, we suggest that the enlarged uteri of rats receiving the serum depends upon FSH in the serum. This view is further supported by data

TABLE 4

COMPARISON OF SERUM FROM A NORMAL NON-PREGNANT MARE WITH TWO SAMPLES OF SERUM FROM MARE 665b IN THE OVARIAN ASCORBIC AGID DEPLETION AND VENTRAL PROSTATE WEIGHT ASSAYS

\begin{tabular}{|c|c|c|c|c|c|c|}
\hline \multirow[b]{2}{*}{$\begin{array}{l}\text { Serum } \\
\text { used }\end{array}$} & \multirow[b]{2}{*}{$\begin{array}{l}\text { Date serum } \\
\text { collected }\end{array}$} & \multicolumn{3}{|c|}{$O A A D$ assay } & \multicolumn{2}{|c|}{$\begin{array}{l}\text { Ventral prostate } \\
\text { weight assay }\end{array}$} \\
\hline & & $\begin{array}{l}\text { Saline control } \\
\text { ascorbic acid } \\
(\mathrm{mg} / 100 \mathrm{ml})\end{array}$ & $\begin{array}{l}\text { Dose } \\
\text { of } \\
\text { serum }\end{array}$ & $\begin{array}{c}\text { Ovarian } \\
\text { ascorbic } \\
\text { acid } \\
(\mathrm{mg} / 100 \mathrm{ml})\end{array}$ & $\begin{array}{c}\text { Dose } \\
\text { of } \\
\text { serum } \\
(m l)\end{array}$ & $\begin{array}{c}\text { Weight of } \\
\text { ventral } \\
\text { prostate } \\
(\mathrm{mg})\end{array}$ \\
\hline Brown Mark* & 28th January 1965 & $75 \cdot 2$ & $2 \cdot 0$ & $60 \cdot 5 \dagger(6)$ & $\begin{array}{l}8 \\
8\end{array}$ & $\begin{array}{l}8 \cdot 4(7) \\
7 \cdot 3(5)\end{array}$ \\
\hline Mare $665 b$ & $\begin{array}{l}\text { 25th March and } \\
\text { 19th April 1964 }\end{array}$ & & $2 \cdot 4$ & $60 \cdot 5 \dagger(6)$ & 8 & $23 \cdot 6(6)$ \\
\hline Mare $665 b$ & 27th January 1965 & & $2 \cdot 4$ & $61.4 \quad(5)$ & 8 & $23 \cdot 5(6)$ \\
\hline
\end{tabular}

Figures in parentheses following values for $\mathrm{mg} / 100 \mathrm{ml}$ ascorbic acid and ventral prostate weights represent the number of rats in the group. Holtzman rats were used for the OAAD assays and 25-day-old Long-Evans for the ventral prostate assays.

* Control serum from normal nonpregnant mare.

$\dagger$ Significantly lower than saline control value.

obtained in hypophysectomized females. In almost every instance the average weights of ovaries and uteri of hypophysectomized females exceeded those of uninjected controls. In two out of eight tests the differences were statistically significant.

Sectioning of the ovaries of these hypophysectomized females revealed some interstitial tissue repair, but measurement of the ten largest follicles in each ovary did not indicate that the follicles were larger than those of uninjected hypophysectomized controls.

Since $30 \mathrm{ml}$ of serum increases the uterine weight in the hypophysectomized animal one might assume that the same dose would stimulate the ovaries and 
uterus in intact females. In other words, even though the anti-FsH in the serum may completely inhibit the endogenous FSH of the intact female rat, the FSH in the serum should synergize with the known high amounts of $L_{H}$ in the serum (as determined in the VPW assay) to produce ovarian and uterine stimulation. However, the data on $30 \mathrm{ml}$ of serum drawn on 4th November 1964 do not confirm this view: the ovaries averaged $13.7 \mathrm{mg}$ as compared to 17.2 for uninjected controls but the difference was not significant; the uteri of the injected animals were significantly $(P=0.05)$ smaller than those of uninjected controls. We have no explanation of this result.

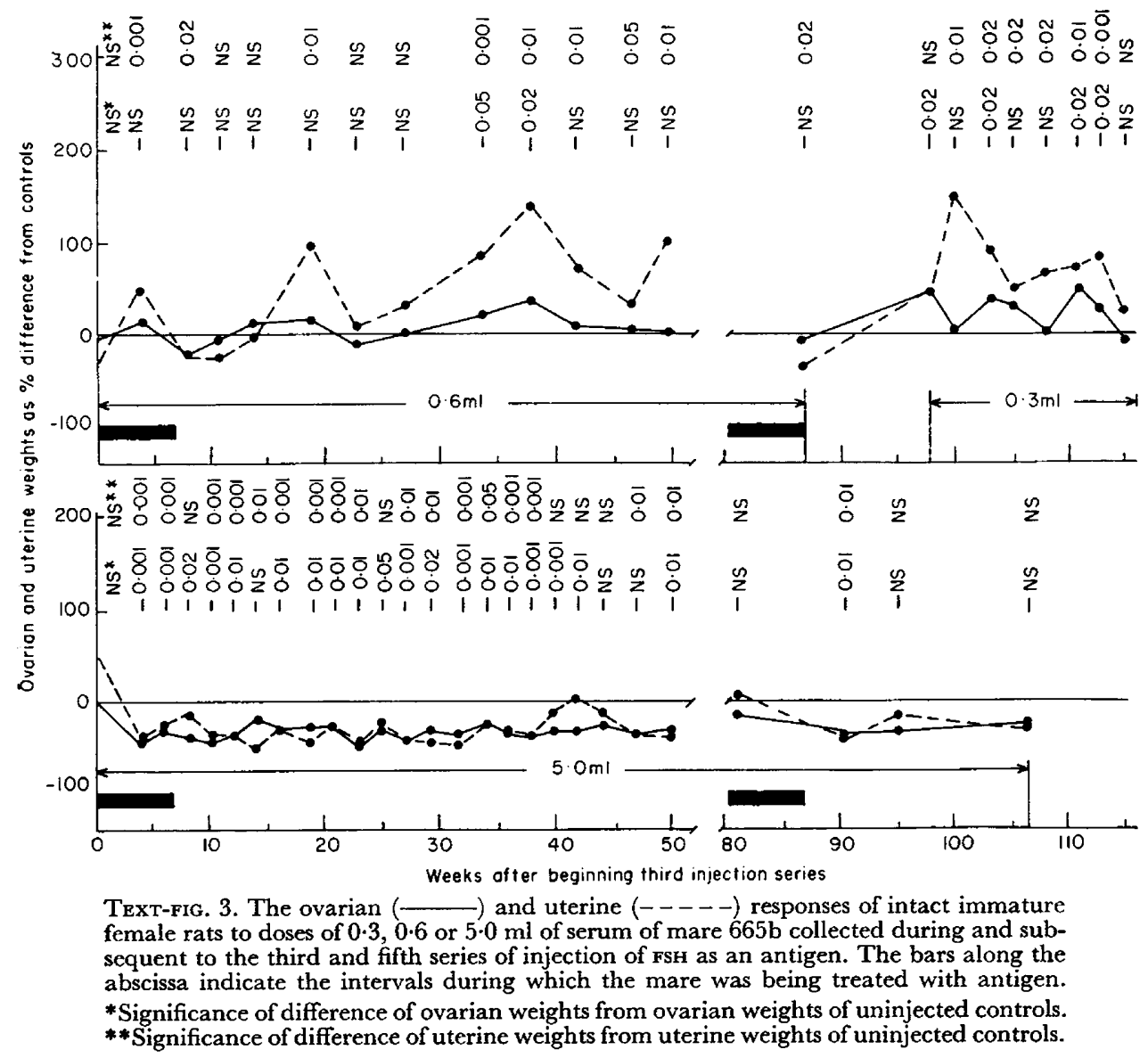

Studies on the serum of mare 665 a receiving $H C G$ as an antigen

Biological effects of the serum. The biological activities of the serum have been described previously (Snook \& Cole, 1964; Cole \& Snook, 1964) and thus we shall merely indicate new information obtained. High levels of gonadotrophin continued to be secreted after the sixth and seventh series of injection of antigen and this hormone produced an effect very similar to that of partially purified pituitary FSH in the intact female. The serum continued to show a strong pro-gonadotrophic response when given with ovine pituitary FSH after the sixth series of injection of antigen. For example, the average ovarian weight of 


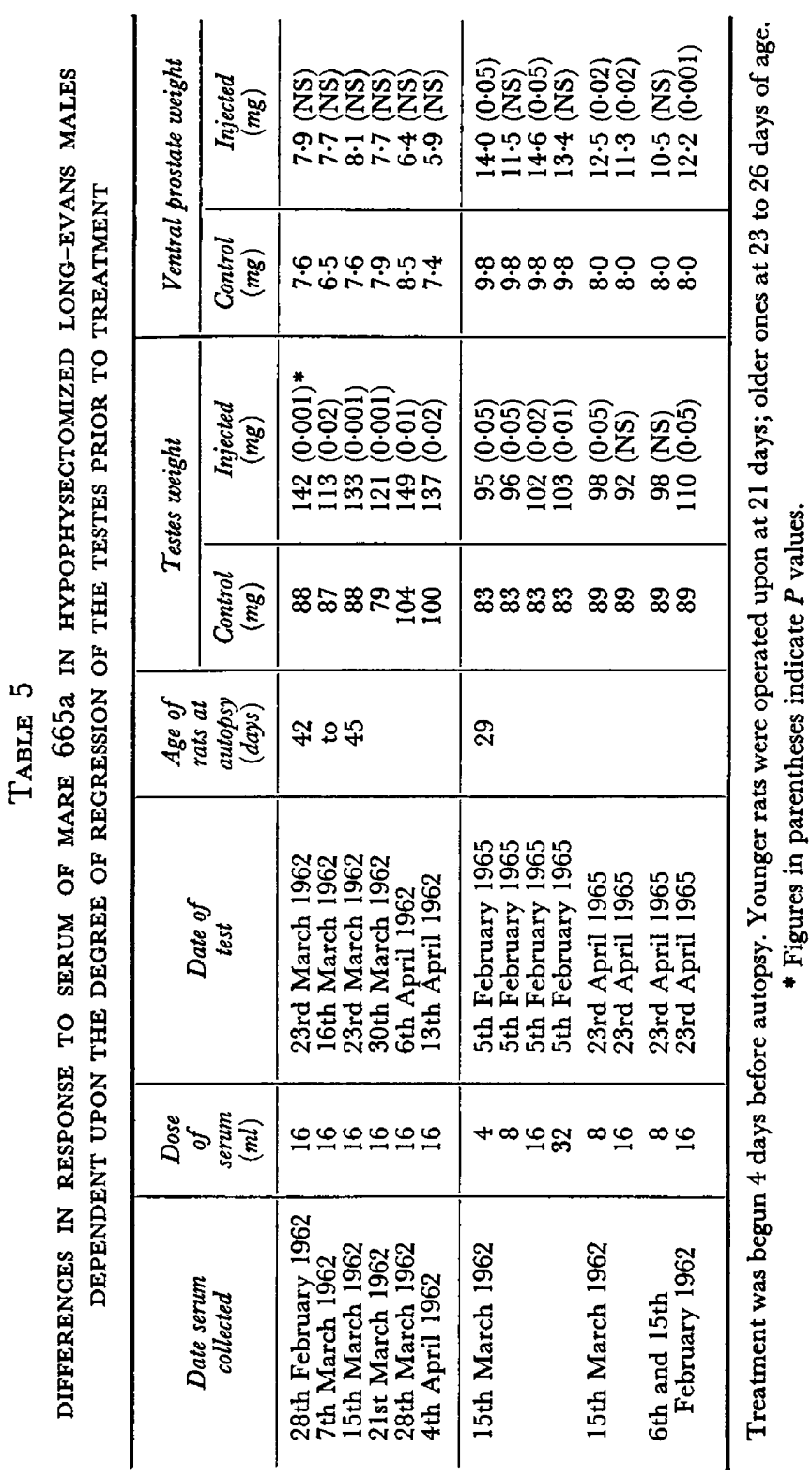


ovaries of ninety rats receiving $5 \mathrm{ml}$ of serum plus $12 \mathrm{mg}$ FSH was $84.4 \mathrm{mg}$ as compared to $47.4 \mathrm{mg}$ in ninety rats receiving $12 \mathrm{mg}$ FsH alone. Fifteen different sera were used in making this comparison. Three sera from untreated mares given in conjunction with FSH produced ovaries weighing $57.4 \mathrm{mg}$ as compared to $45.3 \mathrm{mg}$ for the FsH alone.

As previously reported (Cole \& Snook, 1964) large amounts of serum from this mare (5 to $30 \mathrm{ml})$ depressed testicular weights as well as androgen secretion in the intact male.

In a previous paper (Snook \& Cole, 1964) we reported that the serum of mare 665a stimulated a weight increase of the testes of hypophysectomized male rats, but the sex accessories were unaffected. More recent findings (Table 5) show that this is true in animals in which hypophysectomy was performed at 25 days and injections begun at 38 days of age, but if animals were operated on at 21 days of age and injections begun 4 days later, the testes weight

TABLE 6

ANTI-GONADOTROPHIG AGTIVITY OF FRAGTIONS OBTAINED BY AMMONIUM SULPHATE AND ETHANOL FRACTIONATION OF SERUM FROM MARE 665a (7TH MARCH 1962)

\begin{tabular}{|c|c|c|c|c|c|}
\hline Fraction & $\begin{array}{l}\text { Wt. of } \\
\text { fraction } \\
\quad(g)\end{array}$ & $\begin{array}{l}\text { Rat units } \\
\text { in } \\
\text { fraction }\end{array}$ & $\begin{array}{c}\text { Rat units } \\
/ 100 \\
m g^{*}\end{array}$ & $\begin{array}{c}\text { Estimated } \\
\text { recovery of } \\
\text { activity }(\%)\end{array}$ & $\begin{array}{c}\text { Degree of } \\
\text { purification: } \\
\text { multiple }\end{array}$ \\
\hline $\begin{array}{l}\text { Ammonium sulphate fractionation } \\
\text { (A) Albumin } \\
\text { (GG) } \gamma \text {-globulin with some } \\
\beta \text {-globulin } \\
\text { (OG) Globulins not present in } \\
\text { fraction GG } \\
\text { Total }\end{array}$ & $\begin{array}{c}16 \cdot 25 \\
19 \cdot 32 \\
5 \cdot 23 \\
40 \cdot 8\end{array}$ & $\begin{array}{r}2,167 \\
24,150 \\
10,495 \\
36,812\end{array}$ & $\begin{array}{r}13 \\
125 \\
200\end{array}$ & $\begin{array}{r}9 \\
95 \\
43 \\
147\end{array}$ & $\begin{array}{l}0.2 \\
2 \cdot 0 \\
3 \cdot 2\end{array}$ \\
\hline $\begin{array}{l}\text { Ethanol fractionation of } \gamma \text {-globulin } \\
\text { fraction (GG) } \\
\beta \text {-globulin } \\
\gamma_{1}-\text { globulin } \\
\gamma_{1}-+\gamma_{2} \text {-globulins } \\
\gamma_{2}-\text { globulins } \\
\text { Other } \\
\text { Total }\end{array}$ & $\begin{array}{l}1 \cdot 356 \\
0 \cdot 746 \\
2 \cdot 850 \\
2 \cdot 478 \\
0 \cdot 154\end{array}$ & $\begin{array}{r}608 \\
2,424 \\
9,700 \\
4,850 \\
<100 \\
17,582\end{array}$ & $\begin{array}{r}45 \\
325 \\
375 \\
195\end{array}$ & $\begin{array}{r}5 \\
19 \\
77 \\
39 \\
\\
140\end{array}$ & $\begin{array}{l}0 \cdot 7 \\
5 \cdot 2 \\
6 \cdot 0 \\
3 \cdot 1\end{array}$ \\
\hline
\end{tabular}

* Original serum contained 63 rat units of anti-HCG/100 mg protein.

is increased very little, while the ventral prostate weights are significantly increased over those of controls in five out of eight instances.

Chemical fractionation of antisera. Since the gonadotrophic response obtained with serum of mare 665a in the intact immature female rat, and probably also in the hypophysectomized male rat, is influenced by the anti-gonadotrophic activity of the serum, it seemed desirable to attempt to separate these two activities by chemical fractionation procedures.

Table 6 shows the anti-gonadotrophic activity of the fractions obtained by ammonium sulphate-ethanol fractionation of $485 \mathrm{ml}$ of serum of mare 665a. The albumin fraction contained very little anti-gonadotrophic activity. The bulk of the anti-gonadotrophic activity was found to reside in the $\gamma$-globulin fraction which also contained some $\beta$-globulins, although fraction OG, which contained the remainder of the serum globulins, showed the greatest specific 
activity. When the $\gamma$-globulin fraction was subjected to further fractionation, most of the anti-gonadotrophic activity was found in the fractions comprising the $\gamma_{1}$ - and $\gamma_{2}$-globulins. Fraction GG-AA, which consisted largely of $\beta$-globulins contained very little anti-gonadotrophic activity, while fraction GG-As, the supernatant remaining after precipitation of the remaining globulins with $25 \%$

TABLE 7

GONADOTROPHIC ACTIVITY OF MARE 665a SERUM (7TH MARCH 1962)

AND FRAGTIONS OBTAINED BY AMMONIUM SULPHATE AND ETHANOL FRAGTIONATION

\begin{tabular}{|c|c|c|c|c|c|}
\hline Preparation & $\begin{array}{l}\text { Percentage } \\
\text { of serum } \\
\text { protein }\end{array}$ & $\begin{array}{l}\text { Serum } \\
\text { equivalent } \\
(m l)\end{array}$ & $\begin{array}{l}\text { No. } \\
\text { of } \\
\text { rats }\end{array}$ & $\begin{array}{l}\text { Mean ovarian } \\
\text { weight* } \\
\text { (mg) }\end{array}$ & $\begin{array}{l}\text { Mean uterine } \\
\text { weight* } \\
(\mathrm{mg})\end{array}$ \\
\hline Whole serum & 100 & 10 & 6 & $24 \cdot 2 \pm 1 \cdot 2$ & $31 \cdot 7 \pm 2 \cdot 7$ \\
\hline Whole serum & 100 & 5 & 6 & $\overrightarrow{32 \cdot 3} \pm 1 \cdot 6$ & $57 \cdot 4 \pm 9 \cdot 6$ \\
\hline Whole serum & 100 & $2 \cdot 5$ & 6 & $\overline{30 \cdot 2} \pm 2 \cdot 8$ & $\overline{82 \cdot 3} \pm 11.9$ \\
\hline Whole serum & 100 & $1 \cdot 2$ & 6 & $\overline{17.4} \pm 0.9$ & $\overline{51 \cdot 5} \pm 9 \cdot 3$ \\
\hline A & $41 \cdot 9$ & $2 \cdot 0$ & 4 & $23.9 \pm 1 \cdot 6$ & $\underline{45.9} \pm 0.9$ \\
\hline GG & $49 \cdot 8$ & $2 \cdot 0$ & 4 & $16 \cdot 9 \pm 1 \cdot 2$ & $\overline{70 \cdot 9} \pm 12 \cdot 1$ \\
\hline GG & $49 \cdot 8$ & 1.0 & 6 & $20 \cdot 9 \pm 0.9$ & $\underline{81 \cdot 1} \pm 6 \cdot 1$ \\
\hline OG & $13 \cdot 5$ & $\sim 22 \cdot 3$ & 3 & $27 \cdot 5 \pm 3 \cdot 4$ & $\overline{143 \cdot 6} \pm 7 \cdot 9$ \\
\hline OG & $13 \cdot 5$ & $\sim 5 \cdot 0$ & 6 & $14.2 \pm 1.6 \%$ & $\underline{47 \cdot 0} \pm 3 \cdot 1$ \\
\hline GG-AA & 3.5 & $5 \cdot 0$ & 3 & $\overline{\overline{22 \cdot 0}} \pm 4 \cdot 1 \dagger$ & $\overline{85 \cdot 6} \pm 41 \cdot 3$ \\
\hline GG-AA & $3 \cdot 5$ & $2 \cdot 5$ & 3 & $19 \cdot 0 \pm 2 \cdot 8 \dagger$ & $39 \cdot 1 \pm 4 \cdot 9$ \\
\hline GG-A1B & 1.9 & $5 \cdot 0$ & 3 & $22 \cdot 0 \pm 2 \cdot 3 \dagger$ & $49 \cdot 2 \pm 6 \cdot 6$ \\
\hline GG-A2B & $6 \cdot 7$ & $5 \cdot 0$ & 3 & $23 \cdot 8 \pm 1 \cdot 4 \dagger$ & $86 \cdot 4 \pm 5 \cdot 7$ \\
\hline GG-A2B & $6 \cdot 7$ & $2 \cdot 5$ & 3 & $\overline{22 \cdot 4} \pm 1 \cdot 1 \dagger$ & $1 \overline{11 \cdot 8} \pm 21 \cdot 6$ \\
\hline GG-A2B & $6 \cdot 7$ & $1 \cdot 25$ & 3 & $14.7 \pm 2.7 \dagger$ & $\overline{50 \cdot 1} \pm 3.9$ \\
\hline GG-A3B & $6 \cdot 4$ & $5 \cdot 0$ & 3 & $27 \cdot 7 \pm 5 \cdot 6 \dagger$ & $\overline{71 \cdot 7} \pm 22 \cdot 3$ \\
\hline GG-A3B & $6 \cdot 4$ & $2 \cdot 5$ & 3 & $\underline{23 \cdot 7} \pm 1 \cdot 6 \dagger$ & $91 \cdot 7 \pm 34 \cdot 3$ \\
\hline GG-A3B & $6 \cdot 4$ & $1 \cdot 25$ & 3 & $\overline{16 \cdot 0} \pm 3 \cdot 0$ & $37 \cdot 1 \pm 0.8$ \\
\hline GG-As & 0.4 & $5 \cdot 0$ & 3 & $18 \cdot 0 \pm 1 \cdot 3$ & $30 \cdot 9 \pm 2 \cdot 8$ \\
\hline GG-As & 0.4 & $2 \cdot 5$ & 3 & $14.9 \pm 0.9$ & $35 \cdot 2 \pm 3 \cdot 3$ \\
\hline
\end{tabular}

* Single underlined figures are significantly greater, and the double underlined significantly less than the controls at $P \leqslant 0.05$.

$\dagger$ Weights of organs of six uninjected controls killed on same date were used in determining significance. The weights of the ovaries and uteri of these three control groups were combined and used to test significance of weights of organs obtained with other fractions which had no concurrent controls.

ethanol at $\mathrm{pH} 7 \cdot 4$, contained no measurable anti-gonadotrophic activity. Fractions GG-A1B and GG-A2B containing, respectively, the $\gamma_{1}$-globulins and $\gamma_{1}$ - plus $\gamma_{2}$-globulins showed the greatest degree of purification. The fact that the estimated recoveries exceeded $100 \%$ (Table 6) is probably due to an error in properly estimating recovery rather than an error in properly determining the anti-gonadotrophic titres in the original serum.

Tests for gonadotrophic activity in the same serum, and in the fractions obtained by ammonium sulphate-ethanol fractionation are shown in Table 7. 
Doses of 2.5 and $5 \mathrm{ml}$ of whole serum produced statistically significant increases in ovarian and uterine weights. Generally, those fractions (GG and GG-A2B) which contained the bulk of the anti-gonadotrophic activity gave the best gonadotrophic response. However, a 2-ml serum equivalent of the albumin fraction $\mathrm{A}$, which contained very little anti-gonadotrophic activity, caused a significant increase in uterine weight. The ovarian weight response was significantly decreased by $2 \cdot 5-\mathrm{ml}$ serum equivalents of fraction GG-As and $5-\mathrm{ml}$ serum equivalents of fraction OG. Fraction GG-A2B, which represented the greatest degree of purification of anti-gonadotrophic activity also gave the best gonadotrophic response.

Three experiments were conducted to test the effect of fractionating a pooled sample of mare 665a serum on DEAE-cellulose. In the first two experiments a convex gradient was employed, whereas a linear gradient was used in Experiment 3. A typical elution diagram obtained when $60 \mathrm{ml}$ of pooled serum from mare 665a (6th and 15th February 1963) was chromatographed on DEAEcellulose is shown in Text-fig. 1. A similar pattern was obtained when normal horse serum was chromatographed on DEAE-cellulose, but the heights of the peaks were different.

Anti-gonadotrophic activity was found in all fractions in each experiment. Fraction $G$ in all cases was found to contain very little anti-gonadotrophic activity. In the first experiment the bulk of the anti-gonadotrophic activity was found in fractions $\mathrm{G}$ and $\mathrm{D}$. In the last two experiments, where an attempt was made to divide fraction $B$ into two parts, the bulk of the anti-gonadotrophin was found in fractions $B_{2}$ and $C$. Fraction $B_{2}$ was found to migrate in electrophoresis with a mobility similar to the $\beta$-globulins; fraction $\mathrm{C}$ contained components which migrated with mobilities similar to the $\alpha$ - and $\beta$-globulins. The other fractions were all found to contain moderate amounts of antigonadotrophic activity. The amount of anti-gonadotrophic activity contained in any fraction decreased with distance from the most active fraction. Fractions $B_{1}$ and $B_{2}$ represent better than a 2-5-fold purification of the anti-gonadotrophic activity, while fractions $\mathrm{C}, \mathrm{D}$ and $\mathrm{F}$ show a slight degree of purification.

The best gonadotrophic response in each experiment was obtained with fraction B or a sub-division of fraction B. Five millilitres serum equivalent of fraction $\mathrm{C}$ in all the experiments gave a slight gonadotrophic response. All other fractions appeared to be devoid of gonadotrophic activity, except for fraction $\mathrm{A}$ in the first experiment, which apparently had some activity. In all the experiments it seemed that 5-ml serum equivalents of fraction $\mathrm{F}$ actually caused a decrease in uterine or ovarian weight. The fractions which had the highest titres of anti-gonadotrophic activity in the last two experiments were the ones with the most gonadotrophic activity. Although fraction $\mathrm{B}$ was found to contain very little anti-gonadotrophic activity in the first experiment, fraction $\mathrm{C}$, which contained the bulk of the anti-gonadotrophic activity, appeared also to have some gonadotrophic activity.

The gonadotrophic response obtained with the various fractions was similar to that obtained with serum. The fractions which possessed gonadotrophic activity increased the number of larger follicles, but the follicles did not reach mature size. In one case, fraction $B_{2}$ from the third experiment was found to 
produce ovaries with a few hyperaemic corpora. The diameter of the ten largest follicles in the rat injected with 5-ml serum equivalent of this fraction was $503 \mu$ as compared to $458 \mu$ found previously in uninjected controls, but this difference was not statistically significant.

\section{DISCUSSION}

There are several interesting questions raised by our findings concerning gonadotrophic activity in the serum of mares subsequent to treatment with gonadotrophins as antigens.

A major question is to what extent the gonadotrophic response to the serum is being modified by the presence of anti-gonadotrophins. This question will not be answered until some satisfactory method is available for separating the gonadotrophins and anti-gonadotrophins in the serum; our preliminary attempts have been fruitless in this connection.

In our studies we find that $1 \mathrm{ml}$ of serum of mare $665 \mathrm{~b}$ gives a ventral prostate response approximately equivalent to 8 to $20 \mu \mathrm{g}$ of NIH-LH-s8 in the hypophysectomized L-E 25-day-old male rat and 24 to $34 \mu \mathrm{g}$ in the 23-day-old S-D male rat. This is more than 100 times the highest levels of $\mathrm{LH}$ reported to be present in rat plasma by Nallar, Antunes-Rodrigues \& McCann (1966) and in rat, cow and sow plasma by Anderson \& McShan (1966). By conservative estimate, then, the serum of this $1500 \mathrm{lb}$ mare would contain the equivalent of about $500 \mathrm{mg}$ of NIH-LH-s8.

The discrepancy between the OAAD and VPW responses as compared to those obtained with ovine pituitary $\mathrm{LH}$ should serve as a signal for caution in the interpretation of our findings. Nonetheless, we are unable to explain the VPW responses except on the basis that they are mainly due to luteinizing hormone. Segaloff et al. (1956) and Lostroh et al. (1958) have shown that prolactin may modify the VPW response to $\mathrm{LH}_{\mathrm{H}}$. Albert, Derner, Rosemberg \& Lewis (1965) found that tannation increased the ovine LH potency four-fold in the VPW assay and reduced the LH potency by more than half by the OAAD assay. We (unpublished) have found that the ovine pituitary LH potency is enhanced when serum is the vehicle for injection. These factors, however, do not modify the response to LH to an extent which would explain the divergence of OAAD and VPW responses to mare serum.

That the apparent $\mathbf{L H}$ activity is markedly influenced by the method of assay has been known for some time. For example, Rosemberg, Solod \& Albert (1964) found a twelve-fold discrepancy in LH activity of human menopausal urine extracts (HMG) when tested by the VPW as compared to the OAAD method. They report that the OAAD method is nine times more sensitive than the ventral prostate test for LH prepared from sheep pituitary, but the two methods are equivalent in sensitivity to the gonadotrophin in human menopausal urine.

The LH contaminating 'specially prepared' FSH has been reported by Reichert \& Parlow (1963) and Parlow \& Reichert (1963) to be 50 times more effective by the VPW method than by the OAAD test. Browning \& Larke (1965) show that the discrepancy between the OAAD method and their direct luteinization method is still more striking for NIH-FSH-sl. 
One explanation for the discrepancy in the LH estimation by the OAAD and VPW systems is that there exist differences in the chemical and physical nature of the LH in equine serum and the LH in the ovine standard. Parlow (1963) compared the slopes of the dose-response curves of $\mathbf{L H}$ from seven species in the ventral prostate assay and concluded that the differences in the slopes obtained probably depended upon "true qualitative differences in the biological and, perhaps, in the chemical nature of $\mathbf{L} \mathbf{H}$ ".

The OAAD assay is apparently not suitable for measuring LH activity in horse serum. Few investigators have employed more than one dose level in measuring $\mathbf{L H}$ activity in serum by the OAAD assay. Frankel, Gibson, Graber, Nelson, Reichert \& Nalbandov (1965) in measuring the ovarian ascorbic acid depletion activity of the plasma of adenohypophysectomized cockerels found that the resulting dose-response curve did not deviate from parallelism, but they presented no data.

Several investigators (Pelletier, 1964; Frankel et al., 1965; Anderson \& Bradish, 1965) have reported the presence of ovarian ascorbic acid depletion activity in the plasma of hypophysectomized animals, which could not be detected by other assays for LH. These workers did not, however, rule out the possibility that luteinizing hormone releasing factor may have accounted for the depletion of ascorbic acid. Nallar \& McCann (1965) have shown that plasma from rats 2 to 3 months after hypophysectomy has appreciable quantities of LH-RF. Our studies reported herein on intact male and female rats have been accompanied by studies on hypophysectomized rats in which releasing factors are ineffective.

The nature of the gonadotrophic response to the serum of mare $665 \mathrm{~b}$ in the intact immature female rat is unique. The follicles are enlarged but do not reach mature size and there is no luteinization. This is the same serum which shows the presence of exceedingly large amounts of luteinizing hormone by the VPW test (Tables 2 and 3 ).

The gonadotrophic activity has not been separated from the anti-gonadotrophic activity in the serum either by ammonium sulphate-ethanol fractionation or by fractionation on DEAE-cellulose in these very limited series. By both fractionation procedures, the bulk of the anti-gonadotrophic and gonadotrophic activities were found in the same fractions. In the study where ammonium sulphate-ethanol fractionation procedure was used it was difficult to associate the gonadotrophic and anti-gonadotrophic activities with any particular globulin fraction, as both the globulin fractions showed good gonadotrophic and anti-gonadotrophic activities. When the fraction consisting largely of $\gamma$-globulins was subjected to further fractionation, both gonadotrophic and anti-gonadotrophic activities were concentrated in the $\gamma_{1}$ - or $\gamma_{2}$-globulin fractions and little activity was found in the $\beta$-globulin fraction. On the other hand, when the antiserum was fractionated on DEAE-cellulose, the bulk of the gonadotrophic and anti-gonadotrophic activity appeared to be associated with the fractions containing $\alpha$ - and $\beta$-globulins. The fraction comprising largely the $\gamma$-globulin showed only slight gonadotrophic and moderate anti-gonadotrophic activity.

Although there appears to be some discrepancy as to which serum fraction 
contains the bulk of the gonadotrophic and anti-gonadotrophic activity in the results obtained with the two procedures employed, it should be noted that fraction OG which contained the globulins other than the $\gamma$-globulins and some $\beta$-globulins showed a greater degree of purification than the $\gamma$-globulin fraction. The results of these two fractionation procedures are not strictly comparable because the same serum sample was not used in both fractionation procedures.

The results of this study agree well with the findings of Harrington \& Rowlands (1937) that anti-gonadotrophic activity resides in the globulin fraction. Deutsch \& Nichol (1948), employing an ammonium sulphate-ethanol fractionation scheme upon which ours was based, found that the antibodies in horse serum were distributed among serum fractions showing a wide variation in electrophoretic mobility. They found that the majority of the antibodies were located in the $\gamma_{1}$ - and $\gamma_{2}$-globulin fractions. Recently, Donini, Puzzuoli, D'Alessio, Lunenfeld, Eshkol \& Parlow (1966) have reported that when rabbit antiserum to HCG was fractionated on DEAE-cellulose, the anti-HGG activity was associated with the $\gamma$-globulin and $\gamma$-plus $\beta$-globulin fractions.

The appearance of gonadotrophic activity in the $\alpha$ - and $\beta$-globulin fractions of the antiserum following chromatography on DEAE-cellulose agrees well with the results reported by Pennell (1954), Antoniades, McArthur, Pennell \& Ingersoll (1956), Antoniades, Pennell, McArthur, Ingersoll, Ulfelder \& Oncley (1957), McArthur \& Antoniades (1961) and McArthur, Antoniades, Larson, Pennell, Ingersoll \& Ulfelder (1964) for the location of gonadotrophic activity in human plasma. The results of the ammonium sulphate-ethanol fractionation study also compare favourably with the above reported results, in that all the globulin fractions seemed to have some gonadotrophic activity. It is interesting to note that the albumin fraction obtained by ammonium sulphate-ethanol fractionation of horse antiserum contained some gonadotrophic activity, since studies (McArthur et al., 1964) indicate that the albumin fraction of human menopausal plasma contains FsH activity.

It is obvious, however, from the localization of activities in the $\gamma$-globulin fractions of the ammonium sulphate-ethanol procedure, and the $\alpha$ - and $\beta$ globulin fractions of the DEAE-cellulose procedure, that the gonadotrophic and anti-gonadotrophic activities are not following any of the classical serum proteins for whose separation these procedures were developed. These results also suggest that the sequential use of both procedures may eliminate most of the contaminating serum proteins.

\section{ACKNOWLEDGMENTS}

This study was supported by a grant from the Population Council, Inc., and by Grant AM-06893 of the United States Public Health Service. The authors wish to thank Miss Mary Bigelow for valuable technical assistance.

\section{REFERENCES}

Albert, A., Derner, I., Rosemberg, E. \& Lewis, W. (1965) Assay characteristics of tannate complexes of ovine gonadotropins. Endocrinology, 76, 139.

Anderson, R. C. \& Bradish, A. (1965) Acute ovarian ascorbic acid depletion in the absence of LH. Fedn Proc. Fedn Am. Socs exp. Biol. 24, 321.

Anderson, R. R. \& MCShan, W. H. (1966) Luteinizing hormone levels in pig, cow and rat blood plasma during the estrous cycle. Endocrinology, 78, 976. 
Antontades, H. N., McArthur, J. W., Pennell, R. B. \& Ingersold, F. M. (1956) Preparation of pituitary gonadotropin from human plasma. In: 10th Conference on Plasma Protein and Cellular Elements of the Blood, Protein Foundation Inc., and the Commission of Plasma Fractionation and Related Processes, Cambridge, Massachusetts, p. 37.

Antoniades, H. N., Penneld, P. B., McArthur, J. W., Ingersoll, F. M., Ulfelder, H. \& Oncley, J. L. (1957) Preparation and concentration of the pituitary gonadotropin from human plasma. 7. biol. Chem. 228, 863.

Browning, H. C. \& Larke, G. A. (1965) Direct luteinizing activity of FSH-NIH. Proc. Soc. exp. Biol. Med. 118, 99.

Cote, H. H. \& SNook, R. B. (1964) Biological characteristics of FSH. Proc. Vth int. Cong. A. I. and Anim. Reprod. Trento, 2, 143.

Deutsch, H. F. \& Nichol, J. C. (1948) Biophysical studies of blood plasma protein. X. Fractionation studies of normal and immune horse serum. 7. biol. Chem. 176, 797.

Donini, P., Puzzuoli, D., D’Alessio, I., Lunenpeld, B., Eshxol, A. \& Parlow, A. F. (1966) Purification and separation of follicle stimulating hormone (FSH) and luteinizing hormone (LH) from human postmenopausal gonadotropin (HMG). II. Preparation of biologically apparently pure FSH by selective binding of the LH with an anti-HCG serum and subsequent chromatography. Acta endocr., Copenh. 52, 186.

Frankel, A. I., Gibson, W. R., Graber, J. W., Nelson, D. M., Reichert, L. E., Jr \& Nalbandov, A. V. (1965) An ovarian ascorbic acid depleting factor in the plasma of adenohypophysectomized cockerels. Endocrinology, 77, 651.

Gemzell, G. \& Roos, P. (1966) The physiology and chemistry of follicle-stimulating hormone. In: The Pituitary Gland, vol. 1, p. 492. Butterworths, London.

GreEP, R. O. (1961) Physiology of the anterior hypophysis in relation to reproduction. In: Sex and Internal Secretions, 3rd edn, p. 240. Ed. W. C. Young. Williams \& Williams, Baltimore.

Greep, R. O., Van Dyke, H. B. \& Chow, B. F. (1941) Use of anterior lobe of prostate gland in the assay of metakentrin. Proc. Soc. exp. Biol. Med. 46, 644.

Harrington, C. R. \& Rowlands, I. W. (1937) Fractionation of antithyrotropic and antigonadotropic sera. Biochem. F. 31, 2049.

Lostroh, A. J. \& Johnson, R. E. (1966) Amounts of interstitial cell-stimulating hormone and folliclestimulating hormone required for follicular development, uterine growth and ovulation in the hypophysectomized rat. Endocrinology, 79, 911.

Lostroh, A. J., SQutre, P. G. \& LI, C. H. (1958) Bioassay of interstitial cell-stimulating hormone in the hypophysectomized male rat by the ventral prostate test. Endocrinology, 62, 833.

MCArthur, J. W. \& Antoniades, H. N. (1961) Electrophoretic studies of gonadotropins derived from human plasma and pituitary glands. In Human Pituitary Gonadotropins, p. 201. Ed. A. Albert. Charles G. Thomas, Springfield, Illinois.

McArthur, J. W., Antoniades, H. N., Larson, L. H., Pennell, P. B., Ingersole, F. M. \& Ulfelder, H. (1964) The follicle stimulating hormone and luteinizing hormone content of pooled human menopausal plasma and of subfractions prepared by Cohn methods 6 and 9. J. clin. Endocr. Metab. 24, 425.

Nallar, R., Antunes-Rodrigues, J. \& McCann, S. M. (1966) Effect of progesterone on the level of plasma luteinizing hormone (LH) in normal female rats. Endocrinology, 79, 907.

Nallar, R. \& McGanN, S. M. (1965) Luteinizing hormone-releasing activity in plasma of hypophysectomized rats. Endocrinology, 76, 272.

ParLow, A. F. (1961) Bio-assay of pituitary luteinizing hormone by depletion of ovarian ascorbic acid. In: Human Pituitary Gonadotropins, p. 300. Ed. A. Albert. Charles C. Thomas, Springfield, Illinois.

Parlow, A. F. (1963) Species differences in luteinizing hormone (LH, ICSH) as revealed by the slope in the prostate assay. Endocrinology, 73, 509.

Parlow, A. F. \& Reichert, L. E., JR. (1963) Influence of follicle-stimulating hormone on the prostate assay of luteinizing hormone (LH, ICSH). Endocrinology, 73, 377.

Pelletier, J. (1964) Dosage de l'hormone stimulant l'interstitielle (ICSH) dans le sang par la méthode de l'acide ascorbique ovarien. C. r. hebd. Séanc. Acad. Sci., Paris, 258, 5979.

Penneld, R. B. (1954) Preliminary studies on growth hormone, insulin and gonadotropic factors in human plasma. In: 9th Conference on Plasma Protein and Cellular Elements of the Blood, Protein Foundation, Inc., and the Commission of Plasma Fractionation and Related Processes, Cambridge, Massachusetts, p. 45.

Reichert, L. E., JR \& Parlow, A. F. (1963) Preparation of ovine follicle-stimulating hormone having a high degree of biological purity. Endocrinology, 73, 224.

Rosemberg, E., Solod, E. A. \& Albert, A. (1964) Luteinizing hormone activity of human pituitary gonadotropin as determined by the ventral prostate weight and the ovarian ascorbic acid depletion methods of assay. 7. clin. Endocr. Metab. 24, 714. 
Segaloff, A. (1966) The physiology of the luteinizing hormone. In: The Pituitary Gland, p. 518. Butterworths, London.

Segaloff, A., Steelman, S. H. \& Flores, A. (1956) Prolactin as a factor in the ventral prostate assay for luteinizing hormone. Endocrinology, 59, 233.

SNook, R. B. \& Cole, H. H. (1964) Endogenous gonadotropic activity in mare serum subsequent to chronic treatment with gonadotropin. Endocrinology, 74, 52.

SNook, R. B. \& Cole, H. H. (1965) Bio-assay of antisera against human chorionic gonadotropin. Endocrinology, 76, 20.

Sober, H. A., Gutter, F. J., Wyckofr, M. M. \& Peterson, E. A. (1956) Chromatography of proteins. II. Fractionation of serum protein on an ion exchange cellulose. J. Am. chem. Soc. 78, 756. 